\title{
PRODUKTIVITAS LEMBAR KERJA PESERTA DIDIK (LKPD) PJOK DENGAN PENERAPAN MODEL PROJEK BASE LEARNING PADA PRODI PENJAS FKIP UNIB
}

\author{
Tono Sugihartono \\ Universitas Bengkulu, email : Sugihartono@unib.ac.id \\ Ari Sutisyana \\ Universitas Bengkulu, email : arisutisyana@gmail.com \\ Sugiyanto \\ Universitas Bengkulu, email : sugiyanto@unib.ac.id
}

\begin{abstract}
Abstrak
Penelitian bertujuan untuk mengetahui pengaruh penerapan Model Pembelajaran Projeck Base Learning ( $\mathrm{PjBL}$ ) terhadap peningkatan produk Lembar Kerja Peserta Dididk (LKPD) pembelajaran Pendidikan Jasmani, Olahraga dan Kesehatan (PJOK) pada mata kuliah Perencanaan Pengajaran Penjas dan olahraga. Metode dan prosedur penelitian menggunakan rancangan Penelitian Tindakan Kelas (PTK) berkolaborasi (collaborative classroom action research), subjek penelitian adalah mahasiswa semester $V$ Program studi Penjas FKIP Unib, pada materi Media pembelajaran LKPD. Hasil penelitian menunjukkan bahwa penerapan model pembelajaran Projek Base Learning dalam pembelajaran perencanaan media LKPD mampu memberikan motivasi dan sistem belajar mahasiswa dalam kelompok dalam merencanakan dan membuat produk LKPD, dan mampu memecahkan masalah dalam kelompok secara efektif dan efisien sehingga penguasaan serta keterampilan membuat LKPD dengan ketuntasan mencapai $77,4 \%$. LKPD yang memenuhi kelayakan isi yang terdiri dari indikator materi pembelajaran, materi sesuai dengan kebutuhan belajar dan ketercakupan belajar dengan peningkatan sebesar 20\%. Kesesuaian penyajian LKPD yang meliputi sistematika petunjuk LKPD dengan tugas gerak PJOK, dan isi dengan tugas gerak PJOK, dengan peningkatan sebesar $37,8 \%$. Kesesuaian dengan syarat didaktis yang memenuhi kebutuhan peserta didik dan pengembangan diri peserta didik, meningkat sebesar $30 \%$. Kesesuaian dengan syarat konstruksi (kebahasaan) yang memenuhi kesuaian Penggunaan bahasa dan kalimat, meningkat sebesar 51\%, sedangkan kesesuain LKPD dengan syarat teknis (grafis) yang memenuhi indikator tulisan dan gambar dalam LKPD serta desain /penampilan LKPD, meningkat sebesar $10,7 \%$.
\end{abstract}

Kata Kunci : Model Pembelajaran Projeck Based Learning (PjBL), Lembar Kerja Pseserta Didik (LKPD)

\begin{abstract}
The aim of the sudy was to determine the effect of the application of Model Learning Project Based Learning ( PPA) to increase product students worksheet (LKPD) Learning Education Physical, Sports and Health (PJOK) in the eyes of college planning Teaching Penjas and sports . The methods and procedures of research was used the Classroom Action Research (PTK) design collaborated (collaborative classroom action research), the subject of research was the fifth semester student of the FKIP Unib Physical Education Study Program, on the LKPD learning media material. The results of the study showed that the application of project model based learning in instructional planning media LKPD able to provide motivation and system of learning of students in the group in planning and making product LKPD, and able to solve
\end{abstract}


problems in the group are effectively and efficiently so that mastery and skill make LKPD with completeness reach $77.4 \%$. LKPD who meet eligibility contents of which consist of indicators materials of learning, the material in accordance with the needs of learning and inclusiveness study with an increase of $20 \%$. Conformity presentation LKPD which includes systematic instructions LKPD with the task of motion PJOK, and fill with the task of motion PJOK, with an increase of $37,8 \%$. Conformity with the requirements didactic that meet the needs of the participant students and the development of self-participant students, increased by $30 \%$. Conformity with the requirements of construction (linguistic) accurity of language and sentence, increased by 51\%, while the suitability LKPD with the requisite technical (graphic) that the indicator writing and drawing in LKPD and design / appearance LKPD, increased by $10.7 \%$.

Keywords: Project Model Based Learning (PPA ), Worksheet (LKPD)

\section{PENDAHULUAN}

Dalam amanat kurikulum 2013 bahwa pembelajaran dikondisikan selalu berpusat pada siswa. Begitupun dalam pembelajaran Pendidikan Jasmani, Olahraga dan Kesehatan (PJOK) diharapkan selama jam pembelajaran siswa harus dikondisikan aktif belajar, dalam arti aktif bergerak. Aktivitas siswa tersebut dalam perencanaan guru yang tertuang dalam Rencana Pelaksanaan Pembelajaran (RPP), akan tetapi realisasinya aktivitas siswa hanya berjalan 35\% sampai $45 \%$ saja, artinya kalau pembelajaran di sekolah dasar setiap pertemuan sebanyak 4 jam, 4 × 35 menit $=120$ menit, akan tetapi aktivitas siswa dalam pembelajaran hanya berjalan 40 menit sampai 50 menit saja. Permasalahan ini terungkap melalui observasi selama 2 tahun terahir, baik melalui survey peneliti maupun hasil observasi mahasiswa yang melakukan magang di sekolah mitra di Kota Bengkulu.

Rendahnya aktivitas siswa dalam pembelajaran praktek khususnya, menyebabkan siswa tidak memperoleh haknya yang proporsional untuk memperoleh kebugaran jasmani, karena aktivitas siswa yang diharapkan adalah terpenuhinya waktu siswa bergerak, maupun intensitas gerak yang cukup atau secara frekuensi mengulang berlatih juga harus cukup. Salah satu akar masalah dalam perencanaan pembelajaran yang disusun oleh guru.

Guru belum melengkapi dan belum mengembangkan media pembelajaran untuk meningkatkan dan memotivasi siswa untuk aktif bergerak, bahkan siswa diarahkan untuk aktif dalam bentuk-bentuk aktivitas bergerak yang bervariasi, menarik dan menantang. Guru hanya menggunakan fasilitas yang tersedia apa adanya, maka pembelajarn selesai. Seperti halnya bidang studi lain seperti IPA dan matematika yang mengembangkan pelajaran yang pasif dirubah dengan pendekatan dan model belajaran yang inovatif akan membimbing pada konsep penemuan atau inquiri atau discouvery learning. Dalam prakteknya pembelajaran dipandu dengan lembar kerja siswa (LKS) yang memandu siswa untuk beraktivitas dan bahkan memunculkan kreatif, sehingga pembelajaran menjadi menarik dan menyenangkan, bahkan menjadi ada tantangan. Dalam pembelajaran PJOK justru sangat memungkinkan untuk diterapkan oleh para guru dalam merancang pembelajarannya. Lembar kerja peserta didik (LKPD) dalam PJOK sangat cocok dan tepat untuk dikembangkan para guru, sehingga guru tertantang juga untuk lebih kreatif dalam mempersiapkan diri dan mengembangkan 
diri sebagi guru yang profesional. Sebagian guru yang bertugas dan masih memiliki masalah seperti yang diuraikan di atas, adalah juga merupakan lulusan dari program Penjas FKIP Universitas Bengkulu, menyikapi permasalahn di atas, bagi mahasiswa yang masih menempuh perkuliahan di Prodi Penjas saat ini harus memiliki kemampuan dan keterampilan dalam merancang perencanaan dan pelaksanaan pembelajaran yang lebih baik, oleh karena itu salah satu capaian pembelajaran mata kuliah Perencanaan Pembelajaran Penjas-OR, mahasiswa terampil menyusun perencanaan pembelajaran dalam bentuk Rencana Pelaksanaan Pembelajaran (RPP), dengan perangkat pembelajaran yang lengkap dan memadai dalam mengkondisikan belajar lebih aktif, untuk mencapai tujuan pembelajaran PJOK sebagaimana tertuang dalam Badan Standar Nasional Merancang pembelajaran yang baik, tentu harus dilengkapi dengan perangkat pembelajaran yang memadai juga. Diantara perangkat pembelajaran yang harus disiapkan calon guru adalah media pembelajaran yang berbasis pada aktivitas siswa, yaitu Lembar Kerja peserta didik (LKPD).

Produk dari mata kuliah perencanaan pengajaran Penjas-OR adalah perangkat pembelajaran berupa Silabus, RPP, lembar evaluasi, dan materi, sedangkan LKPD belum termasuk tagihan dari mahasiswa, oleh karena itu penelitian ini ditujukan sebagai upaya peningkatan produk mata kuliah ini berfokus pada pengembangan LKPD dengan menggunakan model pembelajaran berbasis pada Projek base learning.

Berdasarkan perkembangannya media pembelajaran semua mata pelajaran disekolah dapat menerapkan Lembar kerja peserta didik, LKPD merupakan salah satu sarana untuk membantu dan mempermudah dalam kegiatan belajar mengajar sehingga akan terbentuk interaksi yang efektif antara peserta didik dengan pendidik, sehingga dapat meningkatkan aktifitas peserta didik dalam peningkatan prestasi belajar. Menurut Widjajanti (2008:1) bahwa LKPD merupakan salah satu sumber belajar yang dapat dikembangkan oleh pendidik sebagai fasilitator dalam kegiatan pembelajaran.

Strategi dalam proses pembelajaran adalah suatu proses penerapan ide, konsep, kebijakan, atau inovasi dalam suatu tindakan praktis sehingga memberikan dampak, baik berupa perubahan pengetahuan, keterampilan, maupun nilai dan sikap Mulyana (2002). Sementara itu Widdiharto (2004) berpendapat bahwa kebanyakan guru dalam mengajar masih kurang memperhatikan kemampuan berpikir peserta didik, metode yang digunakan kurang bervariasi, dan sebagai akibatnya motivasi belajar peserta didik menjadi sulit ditumbuhkan dan pola belajar cenderung menghafal dan mekanistis. Oleh karena itu dibutuhkan metode pembelajaran yang dapat menumbuhkan suasana menyenangkan, berkesan, tetapi tetap fokus pada materi pembelajaran. Dari berbagai macam model yang ada sesuai dengan diberlakukannya kurikulum 2013 yaitu Model Pembelajaran Berbasis Proyek/ Project Based Learning (PjBL). Menurut Wena (2009) PjBL adalah salah satu model pembelajaran yang inovatif, yang memiliki banyak kelebihan, diantaranya PjBL mampu meningkatkan motivasi belajar peserta didik, meningkatkan keaktifan peserta didik, meningkatkan keterampilan peserta didik, mengembangkan dan mempraktikan ketrampilan komunikasi pada kelompok kerja kooperatif, memberi kesempatan peserta didik dalam mengorganisasi proyek. Sehingga diharapkan peserta didik mampu memperdalam materi dan mampu mengaplikasikan materi yang dipelajari. Model PjBL memberikan kesempatan kepada guru untuk mengelola pembelajaran di kelas dengan melibatkan 
kerja proyek. Model Project Based Learning (PjBL)/ Pembelajaran Berbasis Proyek Rangkaian antara pendekatan, strategi, metode, dan teknik merupakan kesatuan yang tidak terpisahkan dan disebut dengan model pembelajaran.

Pembelajaran PJOK tidak berbeda jauh dari pembelajaran pada umumnya hanya berbeda dalam materi yang disampaikan yaitu gerak manusia. Pembelajaran itu sendiri merupakan sebuah proses interaksi antara peserta didik dengan pendidik dan sumber belajar dalam suatu lingkungan belajar (UndangUndang No.20 Tahun 2003). Dalam pembelajaran PJOK proses pendidikan melalui penyediaan pengalaman belajar kepada siswa berupa aktifitas jasmani, bermain dan berolahraga yang direncanakan secara sistematis guna merangsang pertumbuhan dan perkembangan fisik, keterampilan motorik, keterampilan berfikir, emosional, sosial dan moral (Depdiknas,2007:1).

\section{METODE}

\section{Penelitian dan prosedur penelitian}

Metode penelitian ini menggunakan penelitian terapan (Applied Research), salah satu penelitian ini menggunakan pendekatan Penelitian Tindakan Kelas (Classroom Action Research). Penelitian Tindakan Kelas ( PTK) ini salah satu alternatif penelitian terapan untuk meningkatkan dan memperbaiki Kinerja pembelajaran di kelas atau lapangan (Carr \& Kemmis 1991, dalam IGK Wardani, 2007). Prosedur penelitian yang digunakan dalam memecahkan permasalahan penelitian ini menggunakan rancangan Penelitian Tindakan Kelas (PTK) berkolaborasi (collaborative classroom action research) dengan guru PJOK serta mahasiswa Prodi Penjas . Adapun pelaksanaannya terdiri tiga langkah yaitu: (1) Perumusan masalah, (2) Perbaikan yang terdiri atas beberapa siklus yang meliputi (a) Perencanaan (planning), (b) Pelaksanaan/tindakan (action), (c) Pengamatan (observation \& evaluation), (d) Refleksi (reflexion), dan (3) pemantapan (Beker, 2001; Elliot, 1993; dan Borgg dan Biklen, 1992 dalam Suharsimi Arikunto 2002 ). Dalam hal ini penelitian akan dilakukan sedikitnya 3 siklus, yang tiap siklusnya terdiri dari 2 kali pertemuan terhadap subjek yang diteliti. Tahap-tahap penelitian berikutnya dilakukan secara sistematis seperti langkah-langkah sebelumnya mulai dari perencanaan kembali, pelaksanaan tindakan, observasi dan refleksi.

\section{HASIL DAN PEMBAHASAN \\ Hasil}

Tindakan pembelajaran siklus pertama, pertemuan pertama dilaksanakan pada hari Kamis, tanggal 19 September 2019, dan pertemuan kedua pada tanggal 26 September 2019 masing-masing disajikan selama 2 jam pelajaran $(2 \times 50$ menit). Penerapan projeck base learning pada pertemuan pertama merupakan identifikasi dalam bentuk observasi terhadap model LKPD yang tersedia di media internet atau buku-buku yang tersedia disekolah. Mahasiswa mengakses terhadap model LKPD yang tersedia di media internet atau buku-buku yang disekolah. Setiap mahasiswa mengambil salah satu contoh atau model LKPD pada mata pelajaran PJOK. Tugas diberikan pada mahasiswa seminggu sebelum perkuliahan pertama untuk tindakan penelitian, sehingga pada hari pertama tersebut semua mahasiswa telah memiliki model LKPD masing-masing.

\section{Hasil Observasi siklus 1}

Pada pembelajaran pertemuan kedua teridentifikasi permasalahan baru dan pembahasan perbedaan persepsi tentang LKPD dari RPP yang disusun masing-masing kelompok.

a.Model-model LKPD yang disusun mahasiswa secara umum menunjukkan 
pengertian yang sama, tetapi ada hal-hal yang perlu mendapat kejelasan melalui diskusi dengan dosen pengampu, sehingga masalah dapat diluruskan.

b.Pembelajaran dilanjutkan dengan menyampaikan instrumen untuk menilai LKPD. Mahasiswa menerima materi dan mendiskusikan cara menggunakan instrumen tersebut.

c. Secara berkelompok mahasiswa menilai LKPD dari kelompok yang berbeda,

d. Hasil penilaian LKPD pertemuan kedua merupakan menyempurnakan projek yang memproduk LKPD yang lebih baik dan lebih sempurna.

Tabel 1. Hasil penilaian LKPD pada siklus 1

\begin{tabular}{l|l|c}
\hline No & \multicolumn{1}{|c}{ Jenis penilaian } & Nilai \\
\hline I & $\begin{array}{l}\text { Kelayakan isi } \\
\text { Materi pembelajaran } \\
\text { Materi dengan kebutuhan belajar } \\
\text { Ketercakupan belajar }\end{array}$ & 23 \\
\hline Ii & $\begin{array}{l}\text { Kesesuaian penyajian Ikpd } \\
\text { Sistematika penyajian Ikpd } \\
\text { Petunjuk Ikpd dengan tugas gerak } \\
\text { pjok } \\
\text { Isi dengan tugas gerak pjok }\end{array}$ & 17 \\
\hline lii & $\begin{array}{l}\text { Kesesuaian dengan syarat } \\
\text { didaktis } \\
\text { Kebutuhan peserta didik dan } \\
\text { pengembangan diri peserta didik }\end{array}$ & 7 \\
\hline Iv & $\begin{array}{l}\text { Kesesuaian dengan syarat } \\
\text { konstruksi (kebahasaan) } \\
\text { Kesuaian penggunaan bahasa } \\
\text { dan kalimat }\end{array}$ & 13 \\
\hline V & $\begin{array}{l}\text { Kesesuain dengan syarat teknis } \\
\text { (kegrafikan) } \\
\text { Tulisan dan gambar dalam Ikpd } \\
\text { Desain dan penampilan Ikpd }\end{array}$ & 13 \\
\hline
\end{tabular}

\section{3). Refleksi Siklus pertama}

Masalah yang terjadi pada mahasiswa,bahwa mahasiswa masih menganggap bahwa tugas yang diberikan hanya sebagai formalitas, dan kurang resfect terhadap tugasnya, yang penting mereka mengumpulkan tugas, ternyata masih ada 8 RPP dan LKPD yang sama, artinya mereka mengumpulkan tugas tapi tidak membuat tugas. Oleh karena itu kualitas RPP dan LKPD yang dikehendaki belum sesuai dengan panduan yang digunakan.

(1) Aspek kelayakan isi yang terdiri dari indikator "materi pembelajaran, "materi sesuai dengan kebutuhan belajar" dan "ketercakupan belajar" hanya memperoleh pencapaiannya baru $57,5 \%$, termasuk kriteria nilai Cukup baik

(2) Aspek kesesuaian penyajian LKPD yang meliputi "sistematika petunjuk LKPD dengan tugas gerak PJOK", dan "isi dengan tugas gerak PJOK" diperoleh nilai pencapaian $37,8 \%$. Dengan kriteria kurang baik

(3) Aspek Kesesuaian dengan syarat didaktis yang meliputi indikator "Kebutuhan peserta didik dan pengembangan diri peserta didik" diperoleh nilai 7 dari nilai maksimum 15 artinya pencapaiannya sebesar 46,7 $\%$ dengan kriteria kurang

(4) Aspek kesesuaian dengan syarat konstruksi (kebahasaan) yang indikatornya "kesuaian Penggunaan bahasa dan kalimat" diperoleh nilai pencapaiannya baru 52\%, dengan kriteria cukup, sedangkan

(5) Aspek kesesuain dengan syarat teknis (kegrafikan) yang indikatornya "tulisan dan gambar dalam LKPD" dan desain dan penampilan LKPD" diperoleh nilai pencapaiannya sebesar $52 \%$ dengan kriteria cukup.

Secara keseluruhan kualitas LKPD diperoleh nilai sebesar 73 dari nilai maksimumnya 155 artinya nilai LKPD baru mencapai $47,1 \%$ termasuk pada kategori kurang. Hal tersebut disebabkan kelompok belum sepakat dalam menentukan LKPD yang berkesesuaian dengan syarat didaktis yang indikatornya "Kebutuhan peserta 
didik dan pengembangan diri peserta didik" sehingga mahasiswa dalam kelompok diperlukan bimbingan lebih lanjut. Struktur kebahasaan diperlukan penyederhanaan kalimat yang ringkas tetapi jelas. Sedangkan penampilan grafis di LKPD perlu ditingkatkan sehingga lebih menarik dalam penampilannya.

\section{Siklus kedua.}

\section{Pelaksanaan Tindakan}

Tindakan pembelajaran siklus kedua, pertemuan pertama dilaksanakan pada hari Kamis, tanggal 3 Oktober 2019, dan pertemuan kedua pada tanggal 10 oktober 2019 masing-masing disajikan selama 2 jam pelajaran (2x50 menit). Penerapan projeck base learning pada pertemuan kedua merupakan upaya perbaikan produk LKPD dari tindakan siklus 1. Model LKPD dikelompokkan ke dalam jenis LKPD yang yang homogen, misalnya kelompok LKPD untuk materi permainan bola besar, Senam, Atletik, bela diri, atau permainan bola kecil. Selanjutnya masing-masing kelompok merencanakan dan menyepakati hanya 1 tema yang disusun bersama-sama dengan anggota kelompoknya, tugas diberikan pada mahasiswa selama seminggu.

\section{Hasil Observasi siklus 2}

Selama proses pembelajaran siklus kedua yang disajikan dalam 2 kali pertemuan peneliti mencatat beberapa hal, diantaranya mahasiswa sangat termotivasi dan tertantang untuk melakukan aktivitas dalam kelompok maupun secara individual. Dengan model penyajian pembelajaran projek, dimana tiap mahasiswa harus menghasilkan sebuah produk yaitu RPP dan media pembelajaran dalam bentuk LKPD revisi dari LKPD sebelumnya. Hasil penilaian LKPD pertemuan kedua siklus kedua dengan menyempurnakan projek produk LKPD yang lebih baik dan lebih sempurna.
Tabel 2. Hasil penilaian LKPD pada siklus 2

\begin{tabular}{|c|c|c|}
\hline No & Jenis penilaian & Nilai \\
\hline I & $\begin{array}{l}\text { Kelayakan isi } \\
\text { Materi pembelajaran } \\
\text { Materi dengan kebutuhan } \\
\text { belajar } \\
\text { Ketercakupan belajar }\end{array}$ & 31 \\
\hline li & $\begin{array}{l}\text { Kesesuaian penyajian Ikpd } \\
\text { Sistematika penyajian Ikpd } \\
\text { Petunjuk Ikpd dengan tugas } \\
\text { gerak pjok } \\
\text { Isi dengan tugas gerak pjok }\end{array}$ & 34 \\
\hline lii & $\begin{array}{l}\text { Kesesuaian dengan syarat } \\
\text { didaktis } \\
\text { Kebutuhan peserta didik dan } \\
\text { pengembangan diri peserta } \\
\text { didik }\end{array}$ & 11 \\
\hline IV & $\begin{array}{l}\text { Kesesuaian dengan syarat } \\
\text { konstruksi (kebahasaan) } \\
\text { Kesuaian penggunaan bahasa } \\
\text { dan kalimat }\end{array}$ & 19 \\
\hline $\mathrm{V}$ & $\begin{array}{l}\text { Kesesuain dengan syarat teknis } \\
\text { (kegrafikan) } \\
\text { Tulisan dan gambar dalam Ikpd } \\
\text { Desain dan penampilan lkpd }\end{array}$ & 25 \\
\hline \multicolumn{2}{|r|}{ Total nilai } & 120 \\
\hline & Nilai Ikpd (total nilai/155×100) & 77,4 \\
\hline
\end{tabular}

Refleksi Siklus kedua

Selama proses pembelajaran mahasiswa telah menunjukkan sikap bertanggungjawab terhadap tugas projek yang diberikan, mahasiswa yang sangat resfect terhadap tugasnya, mereka terlihat lebih menunjukkan tanggungjawabnya terhadap projek yang harus diselesaikannya, semua RPP dan LKPD lebih bervariatif dan kreatif, artinya mereka mengumpulkan tugas tidak semata-mata membuat tugas tetapi mereka merasa tertantang untuk menunjukkan kemampuannya. sehingga kualitas RPP dan LKPD yang dikehendaki telah sesuai dengan panduan yang digunakan. Walaupun masih perlu penyempurnaan pada beberapa bagian RPP maupun LKPDnya. 
Berdasarkan tabel 2 di atas, hasil penilaian LKPD bahwa:

a. Aspek kelayakan isi yang terdiri dari indikator "materi pembelajaran, "materi sesuai dengan kebutuhan belajar" dan "ketercakupan belajar" memperoleh nilai 31 dari nilai maksimum 40, artinya pencapaiannya baru $77,5 \%$. Sehingga peningkatannya sebesar $20 \%$.

b. Aspek kesesuaian penyajian LKPD yang meliputi "sistematika petunjuk LKPD dengan tugas gerak PJOK", dan "isi dengan tugas gerak PJOK" diperoleh nilai 34 dari nilai maksimum 45 , artinya pencapaian $75,6 \%$, sehingga peningkatan pada siklus kedua sebesar 37,8\%.

c. Aspek Kesesuaian dengan syarat didaktis yang meliputi indikator "Kebutuhan peserta didik dan pengembangan diri peserta didik" diperoleh nilai 11 dari nilai maksimum 15 artinya pencapaiannya sebesar $76,0 \%$, sehingga diketahui peningkatannya sebesar $30 \%$

d. Aspek kesesuaian dengan syarat konstruksi (kebahasaan) yang indikatornya "kesuaian Penggunaan bahasa dan kalimat" diperoleh nilai sebesar 19 dari nilai maksmumnya 25 , artinya pencapaiannya 76\%, sehingga diketahui peningkatan pada aspek ini sebesar $51 \%$

e. Aspek kesesuain dengan syarat teknis (kegrafikan) yang indikatornya "tulisan dan gambar dalam LKPD" dan desain dan penampilan LKPD" diperoleh nilai sebesar 25 dari nilai maksmumnya 30, artinya pencapaiannya baru 63,3\%, sehingga diketahui peningkatannya hanya $10,7 \%$.

Secara keseluruhan penilaian LKPD diperoleh nilai sebesar 120 dari nilai maksimumnya 155 artinya nilai LKPD baru mencapai $77,4 \%$ dimana pada siklus pertama pencapaiannya hanya sebsar $47,1 \%$, sehingga diketahui peningkatan nilai LKPD siklus kedua sebesar 26,4\%. Bila mengacu pada ketuntasan yang diharapkan maka projek penyusunan LKPD ini masih perlu adanya tindakan lebih lanjut sehingga
LKPD lebih sempurna memenuhi kriteria dan indikator LKPD yang baik.

\section{PEMBAHASAN}

Hasil penelitian dengan produk LKPD diukur keberhasilannya dengan aspekaspek penilaian LKPD yang meliputi Aspek Kelayakan Isi, Aspek Kesesuaian penyajian LKPD, Aspek kesesuaian LKPD, Aspek kesesuaian dengan syarat didaktis, kesesuaian dengan syarat konstruksi (kebahasaan) dan kesesuaian denga syarat teknis kegrafikan. Diuraikan sebagai berikut:

1) Aspek kelayakan isi yang indikatornya "materi pembelajaran," bahwa dalam LKPD harus memuat materi yang berkesesuaian dengan komptensi inti dan kompetensi dasar, sesuai juga dalam merumuskan tujuannya serta harus memenuhi substansi materi pembelajaran yang akan dilaksanakan. Butir materi harus sesuai dengan kebutuhan belajar, artinya bahwa LKPD disusun harus mempertimbangkan kebutuhan peserta didik, dapat menambah wawasan peserta didik, serta memperhatikan tingkat pengetahuan awal peserta didik. Sedangkan indikator "ketercakupan belajar" setidaknya kelengkapan materi akan memberikan kontribusi bertambahnya pengetahuan, pemahaman dan keterampilan siswa.

Pada produk LKPD berdasarkan penilaian menunjukkan peningkatan kualitas yang lebih baik dengan perolehan skor 77,5

2)Menurut Sukintaka (2004) peran pendidikan jasmani sangat besar sumbangannya terhadap peserta didik dalam: a) Memenuhi keinginan untuk bergerak dan mempertahankan gerakan. b) Mengembangkan perasaan terhadap gerakan dan irama, serta penghayatan terhadap ruang, waktu, dan bentuk. c) Menganalisis kemungkinan-kemungkinan gerak untuk dirinya sendiri. d) Memiliki keyakinan terhadap gerakan yang dilakukannya serta perasaan terhadap 
sikapnya. e) Mengembangkan kemampuan gerak dan penyempurnaan gerak dengan melalui latihan-latihan yang teratur, sesuai dengan kemampuannya. Maka aspek kesesuaian penyajian LKPD dengan indikator "sistematika petunjuk LKPD dengan tugas gerak PJOK" meliputi sistematika penyajian, kesesuaian urutan materi pada pembelajaran PJOK; keakuratan data dan fakta pada pembelajaran PJOK; Indikator petunjuk LKPD dengan tugas gerak PJOK, bahwa harus ada kesesuaian petunjuk dan informasi pembelajaran gerak PJOK dan ada bagian untuk menunjukkan keakuratan data dan fakta yang dikumpulkan siswa saat pembelajaran berlangsung.

LKPD juga berisikan tugas gerak PJOK yang meliputi (a) tugas harus sesuai dengan tingkatan tuntutan gerak siswa, keterampilan siswa, kebugaran siswa, mempertimbngkan teknik gerak dan sesuai dengan alat dan media pembelajaran. Pada bagian ini LKPD dinilai dan diperoleh nilai 34 dari nilai maksimum 45, artinya pencapaian $75,6 \%$, dengan demikian diketahui bahwa peningkatan pada siklus kedua sebesar $37,8 \%$.

3.LKPD yang disusun mahasiswa yang menunjukkan aspek syarat didaktis telah terpenuhinya indikator "Kebutuhan peserta didik dan pengembangan diri peserta didik" yang meliputi uraian LKPD dengan memperhatikan perbedaan individu, mendorong peserta didik untuk lebih percaya diri dan bertanggung jawab serta mampu mendorong peserta didik untuk belajar mandiri. Pada bagian ini sangat diperlukan dalam pembelajaran PJOK karena merupakan bagian penting sebagai karakteristik pembelajaran PJOK.

Menurut A.M Bandi Utama (2011) Pendidikan jasmani merupakan salah satu usaha sadar untuk menciptakan lingkungan yang mampu mempengaruhi potensi peserta didik agar berkembang ke arah tingkah laku yang positif melalui aktivitas jasmani. Sesuai dengan hasil penilaian LKPD diperoleh nilai 11 dari nilai maksimum 15 artinya pencapaiannya sebesar $76,0 \%$, sehingga diketahui peningkatan produk LKPD sebesar $30 \%$.

3. Pada aspek kesesuaian dengan syarat konstruksi kebahasaan, LKPD dituntut adanya "kesuaian penggunaan bahasa dan kalimat", yang meliputi penggunaan strktur bahasa yang benar dan jelas, bahasanya mudah dipahami, bahasanya efektif dan efisien, serta dapat menunjukkan kalimat yang komunikatif dan interaktif. $\mathrm{Hal}$ ini penting karena LKPD akan berfungsi sesuai dengan kebermanfaatannya jika uraiannya, perintah dan tugasnya dipahami oleh peserta didik.

Produk LKPD yang disusun ternyata memperoleh nilai sebesar 19 dari nilai maksmumnya 25 , artinya pencapaiannya $76 \%$, sehingga diketahui peningkatan pada aspek ini sebesar $51 \%$.

4. Aspek kesesuain dengan syarat teknis (kegrafikan) sebuah LKPD pada awal pembelajaran akan menentukan kualitas pembelajaran, karena dengan ilustrasi tulisan, gambar, tata letak gambar, desain tampilan, serta ketersediaan ruang peserta didik untuk berkarya baik dalam bentuk tulisan, grafik, dan peta konsep, serta desain penampilan LKPD akan memberikan daya tarik dan motivasi siswa untuk belajar dan beraktivitas. Pada bagian ini nilai LKPD diperoleh sebesar 19 dari nilai maksmumnya 30 , artinya pencapaiannya baru 63,3\%, sehingga diketahui peningkatannya hanya $10,7 \%$.

Pencapaian peningkatan produk LKPD yang merupakan hasil upaya perbaikan hasil karya mahasiswa dengan penerapan model pembelajaran Projek base Learning dimana pada siklus pertama nilai LKPD yang diperoleh mahasiswa sebesar $47,5 \%$, dan setelah tindakan 2 siklus kedua meningkat menjadi $77,4 \%$. Walaupun demikian peningkatan produk LKPD ini masih dapat 
dimaksimalkan dengan seringnya berlatih, diujicobakan sehingga dapat menutupi kekurangan aspek yang perlukan dalam LKPDnya. Dalam penelitian ini menunjukkan bahwa pembelajaran berbasis proyek telah memberikan kesempatan kepada guru untuk mengelola pembelajaran di kelas dengan melibatkan kerja proyek (Wena, 2009). Yang muncul dalam proses pembelajaran adalah terjadinya proses kerja proyek yang sistematis dari mahasiswa, menunjukkan kreativitas dan motivasi peserta didik yang meningkat. Bentuk kerja proyek yang terjadi merupakan open-ended conteksual activity-bases learning, dimana mahasiswa secara berkolaboratif dengan teman kelompoknya beraktivitas dengan upaya untuk memecahkan masalah yang dihadapinya misalnya bagaimana agar LKPD disusunnya dapat lebih baik, lebih menarik dan tepat sasaran untuk mencapai tujuan pembelajaran. Hal tersebut sesuai pandangan Endang Wijayanti (2008) bahwa Kerja proyek dalam Model pembelajaran Projeck base Learning dapat mengatasi bentuk tugas-tugas yang kompleks berdasarkan pada pertanyaan dan permasalahan (problem) yang sangat menantang, dan menuntut peserta didik untuk merancang, memecahkan masalah, membuat keputusan, melakukan kegiatan investigasi, serta memberikan kesempatan kepada peserta didik untuk bekerja secara mandiri.

\section{SIMPULAN DAN SARAN Simpulan}

Berdasarkan hasil penelitian dan pembahasan yang telah diuraikan pada bagian terdahulu, penelitian dapat disimpulkan bahwa pembelajaran dengan penerapan model pembelajaran Projeck Base Learning dapat meningkatkan produk model LKPD yang disusun oleh mahasiswa untuk pembelajaran PJOK di sekolah. Peningkatan hasil karya mahasiswa dalam pembelajaran Perencanaan Pengajaran Pendidikan Jasmani dan Olahraga, karena pendekatan pembelajaran Projeck base Learning memberikan suasana belajar yang menantang, memberikan motivasi, dan tanggung jawab dan mendorong siswa bekerja secara mandiri. Adapun peningkatan hasil penerapan Projek base Learning terhadap produk LKPD sebagai berikut:

a) LKPD yang memenuhi kelayakan isi yang terdiri dari indikator materi pembelajaran, materi sesuai dengan kebutuhan belajar dan ketercakupan belajar dengan peningkatan sebesar $20 \%$.

b) Kesesuaian penyajian LKPD yang meliputi sistematika petunjuk LKPD dengan tugas gerak PJOK, dan isi dengan tugas gerak PJOK, dengan peningkatan sebesar $37,8 \%$.

c) Kesesuaian dengan syarat didaktis yang memenuhi kebutuhan peserta didik dan pengembangan diri peserta didik, meningkat sebesar $30 \%$

d) Kesesuaian dengan syarat konstruksi (kebahasaan) yang memenuhi kesuaian Penggunaan bahasa dan kalimat, meningkat sebesar $51 \%$, sedangkan

e) Kesesuain LKPD dengan syarat teknis (kegrafikan) yang memenuhi indikator tulisan dan gambar dalam LKPD serta desain /penampilan LKPD, meningkat sebesar $10,7 \%$.

\section{Saran}

Hasil penelitian penerapan Problem base Learning dengan produk LKPD PJOK dapat disarankan sebagai berikut:

1) Model pembelajaran Problem base Learning dapat digunakan untuk pembelajaran PJOK baik di SD, SMP dan SMA yang menuntut produk hasil kreativitas siswa tertentu, seperti pengembangan senam irama, model latihan kebugaran, model latihan untuk keterampilan olahraga tertentu dan sebagainya.

2) Pengembangan LKPD dapat dilakukan untuk matakuliah lain 
3) LKPD yang dikembangkan menjadi referensi untuk pengembangan dengan berbasis pada aktivitas gerak, kebugaran, atau penguatan pendidikan karakter, dll.

\section{DAFTAR PUSTAKA}

Arikunto, Suharsimi. Suhardjono. Supardi.( 2007). Penelitian Tindakan Kelas. Jakarta: Bumi Aksara.

Badan Nasional Standar Pendidikan BNSP, (2013) Kemendiknas: Jakarta

Depdiknas.

(2006).

Panduan

Pengembangan Bahan Ajar. Jakarta: Direktorat Pembinaan Sekolah Menengah Atas.

Fajrida, Yunila.(2015). Lembar Kerja Peserta Didik (LKPD). Diakses di http://yafajridabiologiuir.blogspot.co .id/2015/11/lembaran-kerja-pesertadidik-lkpd.html . Pada tanggal 13 Januari 2017 pukul 19.05 WIB

Hopkins, D. (1993). A Teacher's Guide to Classroom Research. Philadelphia: Open University Press.

Indriyani(2013),Mengembbangkan

Penguasaan Konsep Sains dan karakter siswa Melalui Pembelajaran Berbasis Bimbingan. Universitas Pendidikan Indonesia. Repository.upi.edu

Ngalimun, (2012), Strategi dan Model Pembelajaran. Aswaja Pressindo. Yogyakarta

Nurohman, S. (2011). Pendekatan Project Based Learning sebagai Upaya Internalisasi Scientific Method bagi Mahasiswa Calon Guru Fisika. (Online), (http://www.moe.edu.my), diakses 18 mei 2019.

Prastowo, A. (2011) Panduan Kreatif Membuat Bahan Ajar Inovatif. Yogyakarta: Diva Press

Rahma Wahyu, 2016 Implementasi Model
Project Based Learning (Pjbl) Ditinjau Dari Penerapan Kurikulum 2013. Jurnal ,Teknoscienza Vol.1 No.1 Oktober 2016

Riadi, Muchlisin. (2015). Pengertian Lembar Kerja Peserta Didik (LKPD). Diakses dari

http://kajianpustaka.com/2015/07/l

embar-kerja-peserta-

didik.lkpd.html?m=1. Pada tanggal 20

Desember 2018 pukul 23.01 WIB.

Riosa Y.Devi, (2016) Pengembangan Lembar Kerja Peserta Didik (LKPD) PJOK Berbasis Multiple Intelligences Pada Materi Perkembangan Tubuh Remaja Untuk Peserta Didik Kelas VII SMP, Skripsi: UNY.

Rusman. (2013). Model-model Pembelajaran. PT Rajagrafindo Persada. Jakarta.

Soemosasmito.S.,(1997), Efektivitas Pembelajaran Pendidikan Jasmani. Surabaya: Unesa.Press.

Sukintaka. (2004). Teori Pendidikan Jasmani. Bandung : Nuansa Cendekia 